\title{
COMENTÁRIOS SOBRE A OBRA: MÉSZÁROS, István. A educação para além do capital. São Paulo: Boitempo, 2005.
}

Thiago dos Santos Finholdt Vallim ${ }^{1}$

De alta relevância para o investigador crítico que almeja uma compreensão teórica global acerca da importantíssima temática "educação $\mathrm{x}$ transformação social": este nos pareceria um excelente qualificativo para bem resumir o livro de Mészáros em uma só frase. O pequeno texto revela em seu desenvolvimento uma visão lúcida e criteriosa da realidade social em sua co-relação com o sistema educacional operante. Consistentemente fundamentadas, as afirmações apresentadas nesta pequena obra transcrita a partir do discurso oral do pensador húngaro, representam sua formidável intelectualidade, solidamente construída ao longo de décadas de estudos e vivências neste campo. O próprio título da publicação já nos conduz diretamente à síntese da concepção oferecida: são indissociáveis os temas da criação de uma nova alternativa educacional e da transformação social necessária para o futuro da coletividade humana.

Mészáros inicia sua exposição enfatizando que uma transformação educacional verdadeiramente efetiva não poderia se dar no âmbito da simples reprodução ideológica inerente ao sistema de dominação capitalista. Para o autor, as escolas, em geral, têm sido justamente isto: um dos principais instrumentos de controle a garantir a manutenção do vigente sistema alienante de valores. Ele faz críticas categóricas a qualquer tentativa de simples reforma de nossa complexa e injusta organização social, já que, tal empreendimento só faria remediar provisoriamente alguns de seus pontos mais críticos, os quais, por si mesmos, figuram como emblemáticas janelas referenciais, por onde até o olhar menos preparado enxergará com mais clara visibilidade a estrutura contraditória em que a lógica do capital opera.

Mencionando duas experiências historicamente fracassadas neste sentido, a primeira realizada pelo economista Adam Smith e a segunda pelo reformador social e educacional Robert Owen, Mészáros nos dá indicações, ao interpretar a causa defeituosa comum ao mau êxito destes dois pensadores, de que

${ }^{1}$ Acadêmico do quinto período do Curso de Serviço Social da Universidade Federal do Triângulo Mineiro - Uberaba- MG 
as determinações básicas do sistema capitalista são absolutamente incorrigíveis e irreformáveis. Neste sentido, procura demonstrar que elas não podem ser de fato alteradas por um processo parcial e gradual gerido em uma perspectiva basicamente circular - ou fechada em si mesma -, mas apenas através de um rompimento completo com a lógica do capital.

Mészáros afirma a urgência de se planejar uma estratégia eficaz de realização desta tarefa histórica, a fim de que se possa colocar um fim definitivo à legitimação dos interesses dominantes ora fomentada pelo presente aparelho educativo. Esta situação, mantida à custa da contínua introjeção dos ideais capitalistas realizada no seio das escolas, leva à perpetuação do modelo de injustiça que abaliza nosso viver social. Este processo cumpre o objetivo básico de induzir, na forma de dissimulado autoritarismo psicológico, a um conformismo generalizado à ordem estabelecida. Assim, o poder de questionar é quase sempre sonegado aos jovens, que como símbolos de potência transformativa que são, permanecem adormecidos em sua inata e extraordinária capacidade de perceber e alterar o paradigma desumano que caracteriza nosso modo de vida enquanto entes sociais.

Considerada friamente tal realidade, torna-se fácil concluir que uma autêntica possibilidade de emancipação individual e coletiva fica praticamente anulada para a grande maioria de nós, quer sejamos professores ou alunos que funcionemos neste padrão estéril, que é para onde tende a "seguir a maré". Uma contra-internalização desempenhada em termos concretos, que em médio prazo supere a simples negação, não se pode mais fazer esperar; de outro modo, é impossível superar a mediocridade das relações sociais provenientes deste cotidiano mercantil sufocante, que não nos oferece espaço para respirar com um mínimo de liberdade para vivenciar uma maior proximidade de nossa real natureza íntima. É triste constatar que a grande maioria de nós foi acostumada desde a passagem ritual pela educação básica, a ver minadas quaisquer aspirações pessoais de legítima auto-realização humana.

Provocante, o autor vai um pouco mais longe. Afirma - citando Paracelso - que educação, em sua verdadeira e mais ampla dimensão, transcende em muito as instituições formais de ensino; a aprendizagem contempla a totalidade da nossa própria vida, pois o tempo todo estamos agregando alguma forma de conhecimento. Este fato nos indica que qualquer solução digna deve propiciar um impacto diametral à essência da prática sócio-educativa na totalidade de seus aspectos, e não apenas 
na superficialidade de suas delimitações formais. Além do que, na concepção marxista, a "efetiva transcendência da auto-alienação do trabalho" é assinalada como uma tarefa inevitavelmente educacional. E neste ponto convém relembrar que, tal como anteriormente afirmado por Marx, é preciso educar também ao educador. Assim, o papel da educação tem uma abrangência impossível de ser atribuída a qualquer outra instituição, é soberano; é através dela que se pode dar origem à necessária automudança consciente dos indivíduos que deverão atuar como agentes multiplicadores de uma nova ordem social. Aqui Mészáros fala da urgência do surgimento de uma "sociedade de produtores livremente associados".

Segundo Mészáros, é impossível negar que todas as coisas historicamente criadas são impermanentes e, justamente por isso, há a possibilidade real de transformação de toda a estrutura sócio-educacional estabelecida. Para tal, as duas vigas mestras a serem edificadas, capazes de fornecer uma base firme a uma nova e melhor realidade, seriam a universalização da educação e a universalização do trabalho como atividade humana auto-realizadora. Estes seriam dois preceitos essenciais e inteiramente inseparáveis, que, caso traduzidos em ações concretas, promoveriam uma educação para além do capital, funcionando dentro de uma abrangência em muito qualitativamente superior à atual.

Mészáros propõe que este novo modelo de prática social deve ser sustentado através do controle consciente do processo de reprodução metabólica social, de maneira que atuemos como automediadores livres de toda forma alienada de mediação. Poderíamos, desta maneira, fundados na liberdade e na igualdade substantivas, passar para além da visão de nós mesmos como adversários, isentos da artificialidade que surge como produto da busca pela satisfação dos apetites capitalistas que ora movem os mais vigorosos esforços que empreendemos durante nossa curta existência. A educação, promovida neste espírito, poderia ser a grande promotora da consciência que não mais aceita pacificamente a gigantesca desigualdade que nos separa, oriunda dos círculos viciosos de desperdício e escassez que marcam o capitalismo. Assim, seria através da educação que poderíamos reflexionar sobre nossas verdadeiras necessidades e assim definir nossas reais prioridades. "Auto-educação de iguais", "autogestão da ordem social reprodutiva" e "educação continuada" são conceitos que bem expressam os elementos indispensáveis para a superação da manifesta crise estrutural do sistema sob o qual se assenta o capitalismo globalizado. 
Por fim, o autor conclui em tom de convocação: estamos justamente em uma fase de transição, na qual se faz notória a realidade de que a chamada globalização do capital é nada menos que mais uma forma de absurdo a preservar fundamentalmente os interesses dominantes. Em suma, a tarefa educacional que cabe a todos nós, sem exceção, é iniciar uma transformação social profunda, abrangente e libertadora. Neste desafio, cada passo estratégico deve ser dado em consonância com o nobre ideal da emancipação humana, que jamais deve ser perdido de vista, não importa qual seja nosso papel na sociedade. Todos podemos e devemos assumir a condição de protagonistas históricos e mais ainda aqueles que pertencem à área sócio-educativa. $E$ isso não é algo para ser indefinidamente prolongado em vagas teorizações uma vez mais: é coisa de se realizar com fatos, concretamente e da maneira mais prática possível em nossas vidas e em nosso meio; não amanhã: mas agora mesmo. 